\title{
Rob Amery
}

Four Dresdners in South Australia in the early-mid nineteenth century: a lasting legacy for Kaurna, Ngarrindjeri and Barngarla peoples

Tn August 2011, a small delegation from South Australia 1 travelled to Germany on the occasion of the $175^{\text {th }}$ anniversary of the establishment of the Dresden Mission Society, which had sent four young German missionaries to South Australia, beginning with Christian Gottlob Teichelmann and Clamor Schürmann in 1838 followed by Heinrich A. Eduard Meyer and Samuel Klose in 1840.

The delegation which travelled to Germany consisted of Kaurna Elder and educator, Dr Alitya Wallara Rigney, young Kaurna man and cultural performer, Karl Winda Telfer and senior Ngarrindjeri woman and Ngarrindjeri language teacher, Verna Koolmatrie. They were accompanied by mission history researcher and recent German immigrant to Australia, Gerhard Rüdiger ${ }^{6}$, and myself, a non-Aboriginal linguist who has worked for more than 20 years with linguistic materials compiled by the Dresden missionaries. The group visited many sites of significance to the four missionaries. These included the home towns of Schürmann (Schledehausen near Osnabrück) and Teichelmann (Dahme/Mark Brandenburg), the palace in Berlin where Meyer's wife had worked as a tea lady, and locations where they began and completed their training in Berlin and Dresden. In Altenburg, Thuringia they visited the church where Schürmann and Teichelmann were ordained, the Mauritianum Natural History Museum and the Thuringia State

6 Through researching mission history in South Australia, Gerhard Rüdiger discovered that he was married to a descendant of Clamor Schürmann. 
Archives that holds documents central to this story. At the ethnographic section of the Grassimuseum in Leipzig they were shown Kaurna artefacts sent to Germany in 1840, and at the Francke Archives in Halle (Saale) the delegation inspected the archives of the Evangelisch-Lutherisches Missionswerk (LMW) in Leipzig which has inherited the work of the Dresden Mission Society.

Map: Route Taken by the Aboriginal Delegation through Germany, August 2011.

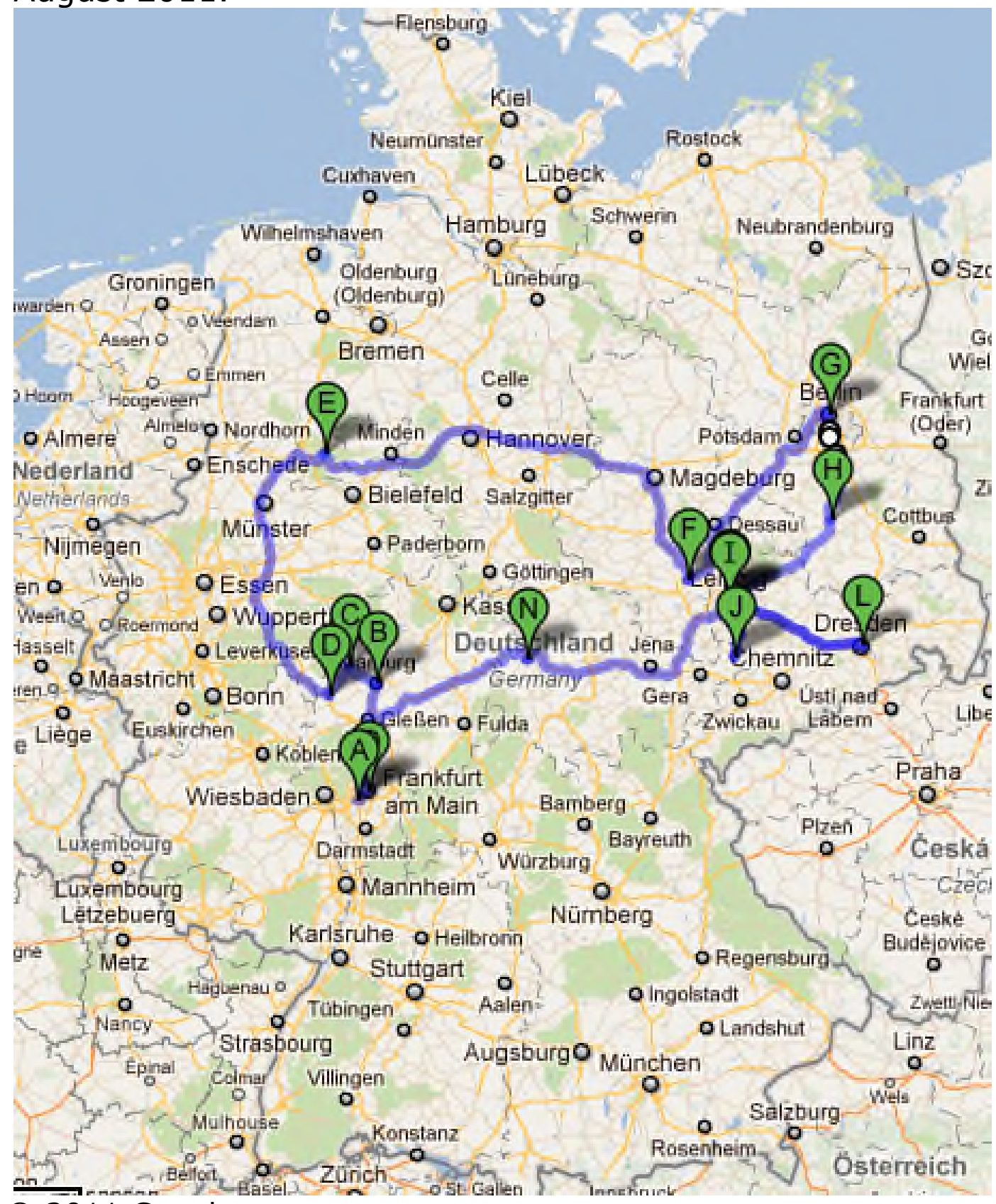

(C) 2011 Google

A - Frankfurt/Main Airport, State of Hesse

B - Marburg, State of Hesse
$\mathrm{H}$ - Dahme/Mark, State of Berlin-Brandenburg I, K, M - Leipzig (Bayerischer Platz), State of 
C - Wallau (Lahn), State of Hesse

E - Schledehausen - Bissendorf, State of Lower Saxony

F - Halle/Saale, State of Saxony (East Germany)

G - Berlin Mitte, State of Berlin
Saxony

J - Altenburg (State of Thuringia)

$\mathrm{L}$ - Dresden (State of Saxony)

$\mathrm{N}$ - Wartburg, Eisenach (State of Thuringia)

O - Frankfurt/Main

This paper will sketch the importance of the work of the four Dresden missionaries and their lasting legacy which is of great value to Aboriginal people, many of whom are descendants of those with whom they worked in South Australia. Their work is also of great value to linguists, ethnographers, historians, archaeologists and other academics. Furthermore the missionaries are of relevance to the Lutheran community in Australia, in particular for their later work with the German immigrant community. However, until recently they have been given scant recognition in Germany. Prior to 2011, for instance, there was no representation of these four missionaries, who were the very first missionaries to be sent overseas by the Dresden Mission Society, on the 'wall of fame' in the basement of the Leipzig mission, though there were photographs of hundreds of other missionaries sent to India, Tanzania and Papua New Guinea. This is mainly due to the fact that there were no Christian converts, and no lasting missions were ever established by the Dresden Mission Society in South Australia. When we visited Dahme, Teichelmann's home town in Brandenburg south of Berlin, no-one had heard of the family. Through the help of the local pastor who researched the records, we did, however, locate the family home which had been unoccupied for some 50 years. By contrast, members of the Schürmann family still live in the vicinity of the Schürmann family farm at Schledehausen near Osnabrück, though it is no longer in the hands of the family. Primarily through Jan Schürmann, descendant of Clamor's older brother, the Schürmann family still takes a keen interest in family history and Clamor's life in Australia and will celebrate a 500-year anniversary at the end of August 2012.

The four German missionaries had an uphill battle from the moment they set foot in South Australia. Teichelmann and 
Schürmann arrived in Adelaide in October 1838, less than two years after the establishment of the colony by the South Australian Company. Although their passage was sponsored by George Fife Angas, a director of the South Australian Company, and even though they had the promise of his ongoing sponsorship, life was hard.

\section{Documentation of Languages}

Upon arrival in Adelaide Schürmann and Teichelmann immediately set about learning and documenting Kaurna, the language indigenous to Adelaide and the Adelaide Plains. Within just eighteen months they published a sketch grammar and vocabulary of around 2,000 words together with some 200 translated sentences. This work, Teichelmann \& Schürmann (1840) is henceforth referred to as T\&S. Whilst this grammar has its shortcomings, it accords well with what we might expect of a language of this type. Aboriginal languages are case marking languages. They typically mark a great many more cases than Latin or German. Kaurna has a range of nominal case suffixes. It marks the agent, or subject of a transitive verb, (Ergative case) with the same suffix as the Instrumental case (eg kaya-rlu 'with a spear'). It also marks Genitive, Dative, Locative, Allative (motion towards as in wawa-ana 'to the beach'), Ablative (motion from as in wawa-nangku 'from the beach') and Perlative (through, along or via as in wawa-arra 'along the beach') cases. Singular, dual and plural pronouns and demonstratives that are inflected for case, and a range of verbal affixes, both inflectional and derivational, were documented, just as we would expect.

Following Schürmann's departure for Port Lincoln in 1840, Teichelmann continued working on Kaurna. A handwritten manuscript of almost 2,500 words liberally illustrated with hundreds of phrases and sentences was sent to Sir George Grey ${ }^{7}$ in Cape Town, South Africa in 1857, followed by a short

7 George Grey was Governor of the colony of South Australia, 18411845. 
manuscript on Kaurna verbs (Teichelmann, 1858). Teichelmann's (1857) wordlist (henceforth TMs) must be read as a companion to T\&S, as it omits many basic words such as kuya (for 'fish') or warto (for 'wombat') that are listed in T\&S. However many words appear in both sources where additional senses have been identified or additional derivations and compounds noted.

In August 1840, Heinrich August Eduard Meyer and Samuel Klose arrived in Adelaide. As Meyer was married he was sent to Encounter Bay, whilst Klose took over the school at Piltawodli where he continued the work commenced by Schürmann eight months earlier. Schürmann, who was actually hoping to establish a mission himself at Encounter Bay, accepted a position as government interpreter at Governor Gawler's insistence at Port Lincoln where he set about learning a third Aboriginal language, Barngarla (Parnkalla) ${ }^{8}$. Schürmann established a second school there in 1850 which was closed in 1852 after funds were withdrawn in favour of the English-only school established nearby by Archdeacon Hale.

In other words, Clamor Schürmann succeeded in learning three Aboriginal languages. At the same time that he was writing a grammar of Kaurna with Teichelmann, Schürmann was busily learning the Ramindjeri language from his Aboriginal language teacher, Encounter Bay Bob, and by January 1840 claimed that he could conduct a conversation with Murray River peoples. There is no trace of Schürmann's notes on the Ramindjeri language but he must have handed these notes on to his close friend and colleague, Eduard Meyer, who published a grammar of Ramindjeri (Meyer 1843). Schürmann published a Barngarla grammar (1844) comparable to their Kaurna grammar, but without the phraseology section. He does, however, include a range of illustrative sentences, a number of which remain untranslated.

${ }^{8}$ Barngarla is the spelling adopted by Barngarla people today though Schürmann spelt it Parnkalla. 
Between 1838 and 1857, the four Dresden missionaries produced grammars of three distinct South Australian languages, short ethnographic works on the associated cultures, translations of religious texts and hymns, and contributed to government reports. They also paved the way for subsequent work by others. The Wesleyan John Weatherstone learnt at the feet of Teichelmann for his endeavours to document the Ngayawang language spoken along the River Murray near Blanchetown (Weatherstone 1843). Protector of Aborigines Matthew Moorhouse was initially critical of the spelling system used by Teichelmann and Schürmann, but eventually adopted their methods himself in his Ngayawang dictionary and grammar (Moorhouse 1846). George Taplin of the Aborigines Friends Association drew heavily on Meyer's earlier work when he established a mission at Point MacLay in 1858, known today by its Ngarrindjeri name, Raukkan. The Hermannsburger missionaries who established a mission at Lake Killalpaninna with the Dieri people in the northeast of South Australia in 1867 drew on the work and experience of the Dresden missionaries (Kneebone 9). Indeed Schürmann had been approached some years earlier in 1863 to establish a mission at Lake Hope, but declined due to his age in favour of "younger stronger men".

Without the work of Teichelmann and Schürmann, our knowledge of the Kaurna language would be very much diminished. Even though there were more than a dozen others who recorded Kaurna language firsthand, the work of the Dresden missionaries is by far the most comprehensive and detailed. Only Black (1920) surpasses them in the quality of his phonetic transcriptions, but Black's wordlist is extremely limited, containing just 66 words in all compared with 3,500 or so recorded by Schürmann and Teichelmann. Without them we would know of far less than 1,000 Kaurna words and we would be much less certain of the form and pronunciation of most of these. Moreover, the meanings of most words would be far less precise and in a number of cases they would be wrong or misleading. We would know only a small fraction of the more complex derivations seen in TMs. The main 
problem, however, would be the absence of a grammar without the work of the German missionaries.

Whilst some other observers did record a small number of sentences, these are all, with the exception of eight phrases and 20 short sentences recorded by Black (1920), Pidgin Kaurna. The true Kaurna language has distinctive Ergative pronouns for the subject of a transitive verb and Nominative/Accusative pronouns for the intransitive subject or object of the verb which are all replaced by the possessive pronouns in Pidgin Kaurna. Case suffixes are invariably missing and verbs typically appear in the present tense form irrespective of the time frame. See Simpson (1996) for an account of Pidgin Kaurna.

As a result, the potential for revival of the Kaurna language would be severely compromised without the work of the German observers, especially as the records of the closely related neighbouring languages to the north are similarly impoverished. We would need to base all sentence construction on the grammatical structure evident in Black's sentences, which are all simple sentences. Whilst past, present and future tenses are recorded, a number of verb suffixes recorded by T\&S are missing and only a few case suffixes are to be found. A reasonable range of pronoun forms is evident, but demonstratives are conspicuously absent. What is more, it appears that Black himself might have relied heavily on T\&S in the interpretation of the material he gleaned from Ivaritji ${ }^{9}$, his one and only source recognised as the 'last speaker' of Kaurna, because he gives T\&S counterparts for almost every word he records.

In reviving a language, if only simple sentences (i.e. sentences with just one verb) are possible, then the resultant language does not flow. It lacks cohesion. The complex sentence constructions found in T\&S and TMs such as the purposive -titya 'in order to',

9 Ivaritji or 'Princess Amelia' was 'discovered' as having links to the Adelaide Plains by Daisy Bates at Point Pearce Mission in 1919 long after the Kaurna people (or Adelaide Tribe) were thought to be extinct. 
conditional -ma 'if', -nanna 'having done', aversive -ttoai 'lest' and various causative constructions allow for a much more complete language. Sentences such as the following would not be possible:

Ninko warra yurrekaityatitya ngai budni (T\&S:G20)

'I came to hear you speak'

Tarralyoanna mutyertanna wondandi, yertabuttonettoai (T\&S:G18)

'Put the clothes on the table, otherwise (they) will get dirty'

Ninna ngattaityangga waanggama, nindaitya aii budnama. (T\&S:G19)

'If you had spoken to me, I would have come to you'

Instead by drawing on Wyatt's vocabulary and Black's morphology and syntax we might be able to say something like:

Ninna wanggandi. Ngai bunata.

'You are speaking. I will come.'

Without the more complex sentences we would be reduced to a very restricted language, unless we were to borrow these constructions from further afield or invent something. Certainly the documentation of Kaurna in T\&S and TMs gives us a firm foundation upon which to build with a reasonable level of confidence. Much the same could be said about Schürmann's documentation of Barngarla and Meyer's work on Ramindjeri. When used alongside of the recordings of others and analysed in the light of genetically related languages which have been documented by linguists and in many cases are still spoken, the linguistic records of the Dresdners make even better sense than if we attempted to use them in isolation.

\section{Ethnography}

The Dresden Four are a rich source of ethnographic information on South Australian Aboriginal peoples in the early days of colonisation. Teichelmann (1841) published a short ten-page ethnography on the Kaurna people of the Adelaide Plains, Meyer (1846) on the Ramindjeri people of Encounter Bay and the 
southern Fleurieu Peninsula and Schürmann (1846) on the Barngarla people of Port Lincoln and Eyre Peninsula west of Adelaide.The fourth, teacher Samuel Klose, preserved the Kaurna language by sending handwritten texts and letters written by Aboriginal students, and hymns translated into Kaurna by Schürmann and Teichelmann to the Dresden Mission Society in Germany where some have survived to this day. Teichelmann also contributed to official government reports (Teichelmann \& Moorhouse, 1841). Valuable insights may also be gleaned from their language descriptions (T\&S; TMs; Meyer 1843 and Schürmann, 1844). Furthermore, the diaries compiled by Teichelmann (1839-1846), Schürmann, (1838-1853) and correspondence sent to Dresden by all four missionaries are also laced with information about the peoples and cultures with whom they worked. Their journals and correspondence are especially rich sources of information on everyday life as they worked with and lived amongst the Kaurna, Ramindjeri and Barngarla peoples. Various conversations are reported, almost verbatim, as they shared their beliefs, visited people in gaol in their hour of need and stood by their friends in the midst of violence on the frontier.

Unfortunately, there is little genealogical information or indication of territorial boundaries. No map or family tree was ever produced. Nor did they record Dreaming narratives in any detail. Teichelmann published brief references in English to a number of Dreaming narratives he had obviously been told in Kaurna and Schürmann recorded in his journal certain religious traditions known as "secret men's business" he had been told by his male informants, not to be relayed to women or children. Unfortunately, none of the Dresden missionaries attempted to record any of these in the respective Aboriginal languages. This is a source of great disappointment today to Aboriginal people associated with these three languages and cultures. In a situation in which so much has been lost due to the ravages of colonisation, information about their land, their families and their cultures, especially spirituality, is highly sought after. 


\section{A Contribution to Science}

Only recently (2010) we discovered that the Dresden missionaries, in addition to their ethnographic descriptions, were collectors of artefacts and natural history specimens for scientific institutions in Germany. In 1840 Teichelmann and Schürmann sent Kaurna artefacts to Dresden. Four of them: a spear, two clubs and a net, were presented by the Dresden Mission Society to the Dresden Museum where they remain in the Museum archives to this day. They are very likely the very first Aboriginal artefacts to have been sent to Germany, though of course there would have been earlier specimens sent to England. We had the privilege of viewing and handling the four artefacts and others, some of which may also have been collected by the Dresden missionaries in South Australia, at the Grassimuseum für Völkerkunde in Leipzig. There is written evidence of more artefacts sent to Altenburg (see map above) in later years, but these have not yet been located.

Teichelmann was corresponding with Hans Conon von Gabelentz in Altenburg, a language researcher and famous in this time. Teichelmann sent Gabelentz a copy of their vocabulary and grammar (T\&S) and possibly also a copy of Meyer's grammar of Ramindjeri. These copies were tracked down by James McElvenny in September 2011 to the Russian State Library for Foreign Literature in Moscow. They clearly belonged to Gabelentz's collection as each still has an "Aus der Bücherei GabelentzPoschwitz" sticker in the inside front cover. Intriguingly, this copy of T\&S had been annotated by Matthew Moorhouse, who served as Protector of Aborigines from 1839 until 1856.

Teichelmann also collected hundreds of bird specimens for the Natural History Society "Osterlande" in Altenburg. When these were 'discovered' by chance in October 2010 by James McElvenny there were 29 specimens on public display in the Mauritianum Natural History Museum. Upon inquiry there were hundreds more specimens in storage which I had the privilege of viewing and photographing in January 2011. Teichelmann also sent insect 
specimens to Altenburg, though these appear not to have survived.

\section{A Linguistic and Cultural Renaissance}

In 1980 Kaurna/Ngarrindjeri woman Leila Rankine sent Narungga man Peter Buckskin, now Dean of the David Unaipon College of Indigenous Education and Research at the University of South Australia, to the archives in search of a name for an alternative school in Adelaide that had just been established. The school was named Warriappendi 'to seek; find'. It is obvious from the spelling that this word was taken from T\&S. This is the first time that Kaurna people had turned to archival material in search of a name. In 1989 efforts to reclaim and re-introduce the Kaurna language began based primarily on the work of Teichelmann and Schürmann (1840). Actually, a facsimile edition of T\&S was printed by Howard Groome in 1982. Groome \& Irving (1981) also produced a book in which they incorporated various sentences, such as Warityanni mai yungainga 'Give some food to Waritya' and Medo wandi wandingai 'I'm going to sleep' etc. taken from T\&S. Words from T\&S, along with some from other sources, were incorporated into short wordlists of kin terms, artefacts, fauna and flora etc. in an Aboriginal Studies resource book on the Kaurna (EDSA 1989).

In 1990 Kaurna revival efforts began with the writing of seven songs that were written wholly or partly in Kaurna (Ngarrindjeri, Narungga \& Kaurna Languages Project, 1990). This was the first time that novel Kaurna sentences, such as Wanti ninna padnendi ngangkitta, yerli? 'Where are you going mother, father? Ngadlu padnendi Kura Yerloanna. 'We're going to Kura Yerlo' and Ngai Murkaota. 'I'll cry' had been constructed since the language was last spoken as a first language prior to 1929, or perhaps even earlier than that. The writing of these songs, with grammatical sentences, would have been impossible without the work of Schürmann and Teichelmann. 
These initial efforts were followed up over the next few years with annual workshops of one or two weeks duration, held mostly at Kaurna Plains School in Adelaide. We began deconstructing sentences from the phraseology section in T\&S and on the basis of our understanding of the grammar that we had gleaned from T\&S we began to construct useful expressions for the classroom. In 1992 a 32-page children's picture book, which included some lengthy and complex sentences, was translated into Kaurna (Amery 1992). Over the years a range of Kaurna language resources have been produced including a songbook (Schultz et al 1999), an alphabet book (Watkins \& Gale 2006), and Kaurna funeral protocols (Amery \& Rigney 2006) such that an entire funeral might be conducted in the Kaurna language if people so desired. A Kaurna Learner's Guide complete with a dozen PowerPoint presentations on a CD with embedded sound files (Amery \& Simpson 2007) has just been revised with new spellings (Amery \& Simpson, in press).

Several websites document the recent achievements of the Kaurna language movement:

- <www.adelaide.edu.au/kwp> provides an introduction to the work of Kaurna Warra Pintyandi, a partnership of Kaurna people and researchers that plans and regulates use of the Kaurna language.

- <www.kaurnaplacenames.com> records Kaurna placenames, their meaning and pronunciation.

- The website "Kaurna in the Public Domain Post-1980" is still in development and will document the many hundreds of requests for naming buildings, organisations, programs, parks etc. with Kaurna names (Amery 2010).

A Kaurna dictionary application for mobile phones (McElvenny 2008) is now in active use by Kaurna language activists. Two hour-long pilot radio programs in and about the Kaurna language are nearing completion and a Kaurna dictionary project is underway. 
The Kaurna language was introduced to Kaurna Plains School in 1992 as their Language Other Than English (LOTE) program and has been taught there ever since. In 1994 a senior secondary Kaurna language course was established at Elizabeth City High School and Elizabeth West Adult Campus in the vicinity of Kaurna Plains School. Kaurna, along with Gupapuyngu in Victoria and Pitjantjatjara in Port Augusta, was the very first Aboriginal language to be taught in Australia at senior secondary level in an accredited program. In 1997 a course in Kaurna language and linguistics was introduced at the University of Adelaide. Kaurna is now taught to more than 500 students each year in a number of government schools scattered throughout the Adelaide metropolitan area. Many more schools would offer this program, if only we could supply the teachers. A TAFE (Technical and Further Education) course has just been developed to train Aboriginal people in the knowledge of their own language at the Certificate III level ${ }^{10}$ and to teach their own language at the Certificate IV level. Over the next few years we are hoping to train a number of Kaurna people to meet this growing demand for Kaurna language programs. See Amery (2000) for a comprehensive account of the reclamation of Kaurna and the establishment of Kaurna language programs.

There is also a strong Ngarrindjeri revival program underway (Gale \& Mickan 2007; Gale 2010). Ngarrindjeri people live along the southern end of the River Murray approximately $100 \mathrm{~km}$ southeast of Adelaide. By contrast to Kaurna considerably more of the Ngarrindjeri language is remembered within the Ngarrindjeri community today. The Ngarrindjeri turned first towards their own memories of the language, some 480 words, which they used liberally and proudly within English in such a way that their speech is at times unintelligible to English speakers. In the 1980s Brian Kirke produced a Ngarrindjeri Yanun language kit which included

${ }^{10}$ Eight Ngarrindjeri students successfully completed the Certificate III course in 2011. 
photocopies of George Taplin's and Meyer's wordlists. As Taplin's wordlist appears with English headwords it was used more than Meyer's which lists Ngarrindjeri headwords. Furthermore, Taplin's name is well-known as he was superintendent of Point MacLeay mission, where many Ngarrindjeri still live today, and which many more still regard as home. Until recently they had taken less interest in Meyer's work undertaken at Encounter Bay some distance away. But Meyer's work underpins that of Taplin and though it was published 35 years earlier, it is a much superior work. Meyer was the first to recognise what is now known as the Antipassive construction, a grammatical construction found in Ergative languages that is analogous to the passive construction in nominative-accusative languages like English or German. Taplin took the earlier work of Meyer and checked his Ramindjeri vocabulary against the Yaralde dialect spoken at Point MacLeay.

Since 2003, Mary-Anne Gale, together with Ngarrindjeri Elders, has been running Ngarrindjeri workshops in Murray Bridge with a group of Ngarrindjeri people. Together they have been exploring the language in more depth. As a result, this group has come to realize the importance of Meyer's work, his insights into Ngarrindjeri grammar and the usefulness of his illustrative sentences.

There has also been some interest amongst the Barngarla people in Schürmann's work. In June 1994 Jane Simpson and David Nash held a Barngarla language workshop in Port Lincoln attended by a dozen or so Barngarla people. Barngarla/Narungga/Kaurna man David Wilson (he identifies with all three language groups) undertook a respelling of Schürmann's Parnkalla and maintained a database in the mid-1990s. Cynthia Rathjen (1998) undertook some preliminary analysis of Schürmann's work on Barngarla and some discussions have been held recently between Prof. Ghil'ad Zuckermann and members of the Barngarla community and an application has been lodged for Commonwealth Government funding to support a Barngarla language program. Should they 
proceed, a revival of Barngarla language will necessarily be based firmly on the work of Clamor Schürmann.

The visit to Germany in August 2011 enabled the South Australian delegation to see where the missionaries, who had worked amongst their ancestors, had come from. To visit the homes and farms where they were raised, to meet some members of the Schürmann family, to walk the streets of the villages and towns they frequented, the churches where they were baptised and ordained and to travel through their homeland, to which they never had the possibility to return, was a moving experience. But especially moving was the opportunity to see the letters at the Francke Foundations, Halle written by Kaurna children Pitpauwe and Wailtyi and the page from Kartanya's copybook. Though Ngarrpadla Alitya Rigney and Karl Winda Telfer had seen images of these documents before, it was quite another thing to see and feel the actual documents and the copious original handwritten correspondence sent back to Germany by the missionaries.

There were also some uneasy moments as the Kaurna and Ngarrindjeri members of the delegation came face to face with artefacts in the Grassimuseum in Leipzig that were made by and once belonged to their people still not knowing the precise circumstances under which they were acquired. Were they purchased or given in exchange or as a gift, or were they simply taken (i.e. stolen)? Later, when confronted with Australian fauna some of the birds that Teichelmann had collected, they felt very uneasy about this, as though their country had been plundered. Again, we did not know a great deal about the circumstances of their collection. They were most likely seen by Teichelmann as a means whereby he could finance their struggling mission in South Australia, but clearly Alitya and Verna felt very uncomfortable about this.

This is what we know about the work of the Dresden missionaries and their record of languages and cultures. Whilst they have left the Kaurna, Ngarrindjeri and Barngarla peoples today with a 
lasting and invaluable record, without which there would be little upon which to build today (especially true for the Kaurna and Barngarla but less so for the Ngarrindjeri), at the same time the missionaries were also part and parcel of the colonial enterprise which decimated their peoples, ransacked and destroyed their country and their sources of food and sustenance and destroyed their traditional way of life which had lived with nature in a longterm sustainable relationship. But perhaps most importantly they contributed to the loss and destruction of their system of beliefs. Whilst the missionaries did what they could to defend the rights of the people with whom they worked and to share what meagre resources they had, they were in direct conflict with Aboriginal people when it came to their beliefs. Many Aboriginal people were prepared to accept the new Christian religion in addition to their own, but the missionaries tried to belittle the traditional Aboriginal beliefs and replace them with Christianity.

On balance, however, the four Dresdners have left the Kaurna, Ngarrindjeri and Barngarla peoples of South Australia a valuable and lasting legacy, unsurpassed at the time in which it was recorded. Whilst they never achieved their goals of establishing lasting, self-sustaining missions and conversions to Christianity and abandoned their work with a sense of despair nonetheless their efforts have resulted in unforeseen success (Amery 2004) with the linguistic and cultural renewal that has taken place over the two decades and more. Despite a prevalent distaste for missions and missionaries amongst many of Australia's Aboriginal people, many Kaurna, Ngarrindjeri and Barngarla people have come to value and cherish much of what Schürmann, Teichelmann, Klose and Meyer achieved through working with their ancestors.

\section{Acknowledgements}

Thanks to Gerhard Rüdiger, James McElvenny and Mary-Anne Gale for comments on an earlier draft of this paper and for Gerhard's tireless efforts in organising the visit to Germany in August 2011. Thanks also to many generous friends in Germany who hosted our visit, to 
Ngarrpadla Alitya Wallara Rigney, Karl Winda Telfer and Verna Koolmatrie for sharing their wisdom and insights and to members of the Kaurna Warra Pintyandi (KWP) group for many years of support.

\section{Bibliography}

Amery, Rob, 1992. Maikoko birko. [Kaurna translation of Christobel Mattingley's Tucker's Mob. Norwood, SA: Omnibus Books].

Amery, Rob, 2004. "Beyond Their Expectations: Teichelmann and Schürmann's efforts to preserve the Kaurna language continue to bear fruit", in: Veit, Walter, ed., The Struggle for Souls and Science. Constructing the Fifth Continent: German Missionaries and Scientists in Australia. Strehlow Research Centre, Alice Springs: Occasional Paper No.3, 9-28.

Amery, Rob, 2000. Warrabarna Kaurna: Reclaiming an Australian Language. Swets \& Zeitlinger, Lisse, The Netherlands.

Amery, Rob, 2010. "Monitoring the Use of Kaurna, the Language of the Adelaide Plains", in: Hobson, John, Lowe, Kevin, Poetsch, Susan and Walsh, Michael, eds., Re-awakening Languages: Theory and practice in the revitalization of Australia's Indigenous languages. Sydney: Sydney University Press, 56-66.

Amery, Rob and Rigney, Alice Wallara with Varcoe, Nelson, Schultz , Chester and KWP, 2006. Kaurna Palti Wonga - Kaurna Funeral Protocols. (book, CD \& Sympathy Cards) Adelaide: Kaurna Warra Pintyandi.

Amery, Rob and Simpson, Jane with Wanganeen, Trent, Buckskin, Vincent (Jack), Goldsmith, Jamie and KWP, 2007. Kulluru Marni Ngattaitya - Sounds Good to Me. A Kaurna Learner's Guide. Draft Prototype Version. Book + CD of PowerPoint presentations with embedded sound files. Adelaide: Kaurna Warra Pintyandi. [Final version to be published by Wakefield Press, Kent Town].

Amery, Rob and Simpson, Jane with Wanganeen, Trent, Buckskin, Vincent (Jack), Goldsmith, Jamie and KWP (in press). Kulurdu Marni Ngathaitya - Sounds Good to Me. A Kaurna Learner's Guide. Kent Town: Wakefield Press.

Black, J. M., 1920. Vocabularies of four South Australian languages, Adelaide, Narrunga, Kukata, and Narrinyeri with special reference to their speech sounds. Transactions of the Royal Society of South Australia 44, 76-93.

EDSA, 1989. The Kaurna people: Aboriginal people of the Adelaide plains. Adelaide: Education Department of South Australia.

Gale, Mary-Anne, 2010. "Bringing the Language home: the Ngarrindjeri dictionary project", in: Hobson, John, Lowe, Kevin Poetsch Susan and Walsh, Michael, eds., Re-awakening Languages: Theory and practice in the revitalization of Australia's 
Indigenous languages. Sydney: Sydney University Press, 387401.

Gale, Mary-Anne and Mickan, Peter, 2007. Nripun your ko:pi: we want more than body parts, but how?, in: Amery, Rob \& Joshua Nash, eds., Warra Wiltaniappendi. Strengthening Languages. Proceedings of the Inaugural Indigenous Languages Conference (ILC) 24-27 September 2007. University of Adelaide, 81-88.

Groome, Howard and Irvine, Jan, 1981. The Kaurna, first people in Adelaide. Largs Bay, SA: Tjintu Books.

Klose, Samuel, 1840 - 1845. Correspondence. Original MSS in German held by the Francke Foundations, Halle. Typescript copies and English translations held by the Lutheran Archives, Adelaide.

Kneebone, Heidi, 2005. The Language of the Chosen View: the First Phase of Graphization of Dieri by Hermannsburg Missionaries, Lake Killalpaninna 1867-80. PhD thesis, University of Adelaide.

McElvenny, James, 2008. Mobile Phone Dictionaries. Endangered Languages and Cultures blog http://www.paradisec.org.au/blog/2008/07/mobile-phonedictionaries/

Meyer, H.A.E., 1843. Vocabulary of the language spoken by the Aborigines of the southern and eastern portions of the settled districts of South Australia. Adelaide: James Allen.

Meyer, H.A.E., 1846. Manners and customs of the Aborigines of the Encounter Bay Tribe: South Australia. (Xerographic facs.) Adelaide: State Library of SA.

Ngarrindjeri, Narrunga and Kaurna Languages Project, 1990. Narrunga, Kaurna \& Ngarrindjeri Songs. Elizabeth, SA: Kaurna Plains School.

Rathjen, Cynthia, 2008. A difficult and boring task: Clamor Schürmann and the language achievements among the Parnkalla, Port Lincoln - 1840-1852. Journal of Friends of Lutheran Archives. 8: 59-95.

Schultz, Chester, Varcoe, Nelson and Amery, Rob eds., 1999. Kaurna paltinna: A Kaurna Song Book. Elizabeth, SA: Kaurna Plains School.

Schürmann, Clamor W., 1838-1853. Journals. Copies of originals in German held by Lutheran Archives Adelaide. English translation held by Anthropology section, South Australian Museum, Adelaide.

Schürmann, Clamor W., 1844. A vocabulary of the Parnkalla language. Spoken by the natives inhabiting the western shores of Spencer's Gulf. To which is prefixed a collection of grammatical rules, hitherto ascertained. Adelaide: George Dehane.

Simpson, Jane, 1996. Early language contact varieties in South Australia. Australian Journal of Linguistics 16, 2, 169-207. Teichelmann, C. G., 1839-1846. Christian G. Teichelmann Diary 1839-1846 and Letters from and to him 1838-1853. Original MSS in German held by the Francke Foundations, Halle. Typescript 
copies and English translations held by the Lutheran Archives, Adelaide.

Teichelmann, C. G., 1841. Aboriginals of South Australia:

Illustrative and explanatory note of the manners, customs, habits and superstitions of the natives of South Australia. Adelaide: Committee of the SA Wesleyan Methodist Auxiliary Missionary Society.

Teichelmann, C. G., 1857. Dictionary of the Adelaide dialect. MS 4 vol. pp. 99 (with double columns). No. 59, Bleek's Catalogue of Sir George Grey's Library dealing with Australian languages, South African Public Library.

Teichelmann, C. G., 1858. Of the verb. MS 8vo. pp. 3. No. 57, Bleek's Catalogue, South African Public Library.

Teichelmann C. G. and Moorhouse, M., 1841. Report on the Aborigines of South Australia. Presented to the Statistical Society in Adelaide. Register (Adelaide), 8 January 1842.

Teichelmann, C. G. and Schürmann, C. W., 1840. Outlines of a grammar, vocabulary, and phraseology, of the Aboriginal language of South Australia, spoken by the natives in and for some distance around Adelaide. Adelaide: Published by the authors at the native location. (Facs. ed. 1962.) Adelaide: Libraries Board of South Australia. (Facs. ed. 1982.) Adelaide: Tjintu Books. A copy annotated by Teichelmann sent to Grey in 1858, held in the Sir George Grey Collection, South African Public Library, Cape Town.

Watkins, Cherie and Gale, Mary-Anne, 2006. Kaurna Alphabet Book. Kaurna Plains School, Elizabeth.

Weatherstone, John, 1843. Vocabulary of native dialect spoken by natives of the <illeg > tribes of natives on the Murray River, South Australia. MS, Methodist Missionary Archives, School of Oriental and African Studies, London. 